\title{
HIV and AIDS knowledge and sexual behaviours amongst secondary school learners in Harare, Zimbabwe
}

\author{
Authors: \\ Margaret Mlingo ${ }^{1}$ \\ Valerie J. Ehlers ${ }^{1}$ \\ Janetta Roos ${ }^{1}$ \\ Affiliations: \\ ${ }^{1}$ Department of Health \\ Studies, University of South \\ Africa, South Africa \\ Corresponding to: \\ Valerie Ehlers \\ Email: \\ ehlervj@unisa.ac.za \\ Postal Address: \\ PO Box 65075, Erasmusrand \\ 0165, South Africa \\ Dates: \\ Received: 26 July 2010 \\ Accepted: 28 Mar. 2012 \\ Published: 13 July 2012 \\ How to cite this article: \\ Mlingo, M., Ehlers, V.J. \& \\ Roos, J., 2012, 'HIV and \\ AIDS knowledge and sexual \\ behaviours amongst secondary \\ school learners in Harare, \\ Zimbabwe', Health SA \\ Gesondheid 17(1), Art.\#570, \\ 9 pages. doi: http://dx.doi. \\ org/10.4102/hsag.v17i1.570
}

(C) 2012. The Authors.

Licensee: AOSIS

OpenJournals. This work

is licensed under the

Creative Commons

Attribution License.
Efforts to stem the tide of the Human immunodeficiency virus (HIV) and Acquired immune deficiency syndrome (AIDS) pandemic in Africa emphasise the necessity that learners should be able to make informed decisions. Although learners in Zimbabwe's schools are taught about HIV and AIDS, the extent of their knowledge needed to be determined. The major objective was to assess the knowledge of secondary school learners in Harare, Zimbabwe, about HIV and AIDS. Structured interviews were conducted with 75 Grade 8 (Form 1) secondary school learners from four schools in Harare.

Most learners had obtained their HIV and AIDS knowledge from schools, but some did so from their parents, community activities, the radio or television. No learner had commenced with sexual activities and all had heard about HIV, but not all knew what HIV was, and even fewer could define AIDS. Less than one-third of the learners could mention the three most important HIV preventive measures. Most learners were willing to undergo voluntary counselling and testing (VCT), but few had done so. As no learner had commenced sexual activities, opportunities existed to empower Grade 8 (Form 1) learners with adequate HIV and AIDS knowledge. Generally the learners' HIV and AIDS knowledge levels were high but some misconceptions existed. Schools should engage with radio and television programmes to address misconceptions about HIV and AIDS. Learners should be enabled to access VCT services. More effective HIV prevention education in Zimbabwe's schools, could enable more youth to remain HIV negative.

Pogings om die Menslike Immuniteitsgebrekvirus (MIV) en Verworwe immuniteitsgebreksindroom (VIGS) pandemiese golf in Afrika te stuit, beklemtoon die noodsaaklikheid dat leerders ingeligte besluite moet kan neem. Alhoewel leerders in Zimbabwe se skole onderrig word oor MIV en VIGS, behoort die omvang van die kennis vasgestel te word. Die hoofdoelwit was om sekondêre skool leerders van Harare, Zimbabwe, se MIV en VIGS kennis te bepaal. Gestruktureerde onderhoude is gevoer met 75 Graad 8 (Vorm 1) sekondêre skool leerders van vier skole in Harare.

Die meeste leerders het hulle MIV and VIGS kennis by skole opgedoen terwyl 'n paar dit van hulle ouers, gemeenskapsaktiwiteite, die radio en televisie gekry het. Geen leerders het met seksuele aktiwiteite begin nie, almal het van MIV gehoor, maar nie almal het geweet wat MIV is nie, en nog minder kon VIGS definieer. Minder as een-derde kon die drie belangrikste MIV voorkomende maatreëls noem. Die meeste leerders was gewillig om vrywillige berading en toetsing (VBT) te ondergaan, maar min het dit reeds gedoen.

Aangesien geen leerder seksueel aktief was nie, bestaan geleenthede om Graad 8 (Vorm 1) leerders te bemagtig om ingeligte besluite te neem. Oor die algemeen was die leerders se MIV en VIGS kennisvlakke hoog, maar wanopvattings het bestaan Skole behoort saam te werk met radio en televisie programme ten einde wanopvattings aan te spreek. Leerders moet in staat gestel word om VBT dienste te benut. Doeltreffender MIV en VIGS voorligting in Zimbabwe se skole, kan meer jong mense in staat stel of HIV negatief te bly.

\section{Introduction and background information}

Acquired immune deficiency syndrome (AIDS) is an infectious disease that is caused by the human immuno deficiency virus (HIV). The virus affects and destroys the immune system and causes infected people to become more prone to opportunistic infections (Lindsay 2001:S4). Sub Saharan Africa (SSA) is the worst affected area in the world, with $64 \%$ of all people with HIV living in SSA (Joint United Nations Programme on HIV and AIDS [UNAIDS] 2006:15) and half of the new cases are amongst people aged 15-24 years (UNAIDS 2004:93).

Nearly half of the population of Zimbabwe (43\%) is comprised of young people aged 15 or younger. HIV prevalence rates amongst Zimbabwe's young people aged $15-19$ years was $12 \%$ for 
women and $2 \%$ for men (Ministry of Health and Child Welfare (MOHCW) 2003:14). HIV prevalence for young women, attending antenatal clinics in Harare, the capital city of Zimbabwe, ranged from $28 \%$ amongst women aged 15 years to $33 \%$ amongst women aged 21 years (MOHCW 2000:26). In Zimbabwe the age group of 6 to 15 years was least infected with HIV (MOHCW 2004:14). The hope of slowing down the spread of HIV amongst young sexually active persons remains a challenge. The future of the AIDS epidemic will be shaped by the sexual behaviour of this younger age group as it has the lowest level of infection. Hence there is an urgent need to aim HIV prevention strategies at them whilst they are still likely to be HIV negative. According to Zimbabwe's Young Adult Health Survey (MOHCW 2001-2002:70) human behaviour relating to HIV is influenced by different factors which include:

- knowledge of this infection

- risk perceptions of and attitudes towards condoms

- perceptions of persons infected with HIV

- gender roles.

However, knowledge is reported as an important influential factor on sexual behaviours. A review of social science research about HIV and AIDS (Freudenthal 2001:12) showed that many researchers consider education to be one of the most important tools for preventing the transmission of HIV. A joint press release by the United Nations International Children's Emergency Fund (UNICEF), Joint United Nations Programme on HIV and AIDS (UNAIDS) and the World Health Organization (WHO) stated that there was a strong linkage between what young people knew and how they acted (UNICEF 2002:1). Although there is no guarantee that knowledge leads to behaviour changes, at least HIV and AIDS knowledge should enable young people to make informed decisions.

A Zimbabwean survey (MOHCW 2001-2002:1) reported that many of its youth engaged in behaviour that put them at risk of HIV infection, and 71\% of young persons aged $15-29$ years had sexual intercourse before the age of 20 . The age of sexual intercourse, the degree of sexual activity and the number of sexual partners are factors that increase the risk of HIV amongst the youth (Buseh, Glass, McElmurry, Mkhabela \& Sukati 2001:526). Two studies in Zimbabwe showed that many male adolescents were sexually active by the age of 15 and, therefore, at risk of HIV infection (Boohene, Tsodzai, Hardee-Cleveland, Weir \& Janowitz 1999:266). In Harare, amongst the age group 15-24, HIV prevalence reportedly remained at 20\% in 2005 (MOHCW 2005:27), hence the need to provide targeted HIV information for this age group, enabling them to make informed choices.

According to the MOHCW survey (2001-2002:31), young people engage in high risk behaviours like alcohol and drug abuse, early sexual debuts and sex with older men who might be infected with HIV. Mataure et al. (2002:217) reported that $63 \%$ of females and $70 \%$ of males in Harare's secondary schools drank alcohol and that they engaged in high risk sexual behaviour whilst intoxicated. Girls had sex with older men in exchange for money whilst boys had sex with casual sex workers. Fritz et al. (2002:227) found a strong association between alcohol consumption and sexual risk behaviours in Harare. A survey of experiences of young people in urban Zimbabwe reported that they engaged in sexual activity, prostitution, drug and alcohol abuse at an early age (Phiri 2000:4-9).

\section{HIV and AIDS education offered in Zimbabwe's schools}

The education system in Zimbabwe is divided into primary (Grades 1-7), secondary (Grades 8-12, but called Forms 1-6 in Zimbabwe) and tertiary education, offered by colleges and universities. There are low-density, high-density, private and rural schools. In Harare there are 209 primary schools and 85 secondary schools (Ministry of Education, sports and Culture, Zimbabwe (MOESC) 2005:2).

As from 1993, Zimbabwe's education system included HIV and AIDS programmes in all primary and secondary schools (Grades 1-12). The purpose of this HIV and AIDS school programme is to provide knowledge about HIV and AIDS to learners, to promote healthy lifestyles, positive values and attitudes and responsible behaviour amongst learners (MOESC 2003:5). This is in line with the Zimbabwe National HIV and AIDS policy which states that children should have access to knowledge and life skills that are needed to avoid HIV infection (MOHCW 1999:22).

The curricula for primary and secondary school learners address the following:

- human growth and development

- information about HIV and AIDS (what it is and how it is acquired, transmitted and prevented)

- life skills that promote positive behaviour changes

- the impact of HIV and AIDS on individuals, families and the nation

- promoting behaviour that prevents and reduces this infection and its transmission amongst learners (MOESC 2003:6-7).

The basic HIV and AIDS knowledge of secondary school learners should at least encompass the ABC (abstain from sex, be faithful to one sexual partner, and use condoms) of HIV and AIDS prevention. The fourth aspect (D indicating diagnosis) involves voluntary counselling and testing (VCT) about which learners should also be knowledgeable (MOESC 2003:4).

\section{Statement of the problem}

HIV infection amongst the age group 5 to 14 years is reportedly low in Zimbabwe with 120000 children living with HIV compared to 1.8 million adults in 2001 (Lindsay 2001:1). Zimbabwe's Ministry of Education has included HIV and AIDS education in its school curricula since 1993. In Zimbabwe no information on the level of HIV knowledge amongst young people aged up to 15 years could be traced. 
Thus, there appeared to be a need to evaluate the HIV and AIDS knowledge of Zimbabwe's learners and to assess their reported sexual behaviour. Based on these findings, recommendations could be made for enhancing the messages conveyed during HIV and AIDS information sessions in Zimbabwe's schools.

\section{Definitions of key terms}

Secondary school learners: are learners who have completed seven years of primary schooling and are in their first year (Grade 8 or Form 1) in a secondary school in Harare, Zimbabwe.

Youth and young people: include the terms 'adolescent' and 'teenager', referring to young people who are undergoing the physical, mental and cultural transition from childhood to adulthood. According to the WHO (2006:1) adolescents are people aged 10-19 years and young people 10-24 years. In Zimbabwe youth and young people fall within the age group of 10-30 years. (Ministry of Youth Development, Gender and Employment Creation (MYDGEC) 2000:12). For the purpose of this study, young people will refer to people aged 10-30 years, as defined by the Zimbabwe National Youth Policy, and will be used interchangeably with youth.

\section{Significance of the study}

Information obtained about the HIV and AIDS knowledge and sexual behaviour of the learners could help to assess the impact, of the HIV and AIDS curricula in Zimbabwe's schools, on the HIV and AIDS knowledge of learners, and on their reported sexual behaviour. Recommendations could enhance the impact of the HIV and AIDS curricula, in Zimbabwe's schools, on the HIV and AIDS knowledge of secondary school learners, by addressing knowledge areas in which learners might require more information

\section{Purpose and objectives of the study}

The purpose of the study was to assess the knowledge about HIV of secondary school learners in Harare. Recommendations, based on the study's findings, could enhance the impact of Zimbabwe's HIV and AIDS school programmes on the knowledge levels about HIV and AIDS of secondary school learners, and, thus, on their abilities to make informed decisions about their sexual behaviours.

\section{Research method and design \\ Research design}

A non-experimental, exploratory and descriptive quantitative approach was followed. According to Brink (2006:108), a non-experimental study is carried out in a natural setting and the phenomena are observed as they occur. Data can be collected without making changes or introducing treatments. This design was chosen because it allowed the collection of data in the natural setting of secondary schools. Exploratory studies address issues that have not been previously studied in order to identify new knowledge, new understandings or new meanings of the issues (Polit \& Hungler 2008:19).
Descriptive designs describe variables in order to answer the research question(s) (Brink 2006:109). In quantitative research numbers are used, based on statistical analyses, to describe phenomena (Brink 2006:109).

The exploratory descriptive design has been chosen because it could generate new information, about the knowledge of HIV by secondary school learners, that could influence their chances of remaining HIV negative. The quantitative design was chosen because it enabled the interviewer to remain objective and to ask the learners factual questions.

\section{Population and sample}

The study population comprised girls and boys who had completed seven years of primary schooling and were in their first year at secondary school. The number of Form 1 learners in Harare's 209 secondary schools during 2008 could not be determined. As a result of limited funds, severe fuel shortages that made travelling unreliable and expensive, four schools accessible to the interviewer for data collection were selected (The first author conducted all the interviews). The secondary schools were purposefully selected to include one high density school, one low density school, one rural school and one religious (private) school. A convenience sample was used because it involved learners who happened to be 'in the right place at the right time' (Burns \& Grove 2001).

Form 1 learners from the four selected schools could participate, provided their parents had granted them permission and provided the individual learners were willing to be interviewed on the days when the interviewer visited their particular school. Learners who were not in Form 1 at the four participating schools were excluded, as well as those whose parents did not give their permission, or who were unwilling to be interviewed, or who were absent from school on the days when the researcher visited their particular school.

At each participating school, all Form 1 learners were invited to participate in the study and and requested to obtain written permission from their parents. Ten girls and ten boys from each participating secondary school were expected to take part in the survey. However, the total sample size comprised 75 Form 1 learners ( 39 girls and 36 boys). The first 10 male and the first 10 female volunteers were interviewed from each school, but only 15 learners from the high density school participated. The school principals specified that a maximum of ten male and ten female learners could be interviewed at each school to minimise the potential disruption to the ongoing school programme.

\section{Data collection instrument}

Data were collected by implementing structured interview schedules containing both open and close-ended questions. These addressed the following aspects of the research:

- demographics (age, gender, religion, type of school attended) 
- HIV knowledge

- HIV prevention methods

- sources of HIV knowledge

- sexual behaviours.

Questions about HIV knowledge focussed on the learners' ability to define HIV and AIDS and describe its modes of transmission. Learners were requested to list three behaviours that could ensure that a person would remain HIV negative, to assess their HIV prevention knowledge. Questions were also asked about the learners' knowledge about voluntary counselling and testing (VCT) services, and their utilisation of VCT services. Questions about the learners' sexual behaviour requested information about their sexual activities, their knowledge about the advantages of using condoms and where they may access condoms.

The structured interview schedule was specifically designed to collect data about the HIV and AIDS knowledge of secondary school learners. It was based on the literature reviewed and on Zimbabwe's school HIV and AIDS programme's guidelines. The interview schedule was reviewed by a statistician and two experienced nurses who were also researchers. The instrument was pre-tested by conducting interviews with Form 1 learners from two schools who did not participate in the actual study. No problems were encountered whilst pretesting the instrument.

\section{Data collection process}

The interviewer visited each participating school and obtained suitable dates for conducting the interviews from the principals concerned. Information about the survey was handed to Form 1 learners who were requested to obtain written permission from their parents to participate in the survey. On the appointed date, the researcher conducted face-to-face structured interviews with the first ten male and with the first ten female learners who produced signed permission from their parents, and who declared that they were willing to be interviewed.

One researcher conducted all of the interviews and asked the same questions in the same sequence from all learners. The interviewer recorded all the responses on the interview schedule. Responses to open-ended questions were recorded verbatim.

\section{Data analysis}

Data were coded and analysed using the Epi Info 2004 version 3.2.2 program. A statistician assisted with data analysis. Responses to open-ended questions were grouped, counted and analysed quantitatively. Descriptive statistics, mostly frequencies and percentages, were calculated.

\section{Results}

\section{Demographic data}

A total of 75 learners were interviewed from four schools identified as:
- A, representing a low density school $(27 \% ; n=20)$

- B, a private school $(27 \% ; n=20)$

- $\quad$, a high density school $(20 \%$; $n=15)$

- $\mathrm{D}$, a rural school $(27 \% ; n=20)$.

There were more female $52 \%(n=39)$ than male $48 \%(n=36)$ respondents. The learners' ages ranged from 12 to 14 years; $69.3 \%(n=52)$ of the respondents were 13 years old, followed by learners aged 14 years $(26.7 \% ; n=20)$ whilst learners who were 12 years old were in the minority $(4 \% ; n=3)$. The age range is consistent with learners who have completed seven years of primary education in Zimbabwe, given the fact that they enrolled in Grade one at six years of age and had completed at least seven years of schooling when the data were collected.

Reportedly all learners $(100 \% ; n=75)$ were Christians. Of the learners $68 \%(n=51)$ grew up in urban areas; $17.3 \%(n=13)$ in small towns and $14.7 \%(n=11)$ in rural areas. Stratified by gender, more males $(19.4 \% ; n=7)$ than females $(10.3 \%$; $n=4$ ) grew up in the rural areas and almost an equal number of males and females grew up in urban areas.

\section{Learners' HIV and AIDS knowledge Sources of HIV and AIDS knowledge}

All learners $(100 \% ; n=75)$ had heard about HIV and AIDS. The school $(92 \% ; n=69)$ was the most frequently mentioned source of this information. Television $(60 \% ; n=45)$ and radio $(41.3 \% ; n=31)$ were also common sources of information.

\section{Learners' HIV and AIDS knowledge levels}

When asked what HIV is, $94.7 \%(n=71)$ of the learners answered correctly, although 100\% $(n=75)$ had heard about HIV. Although all learners $(100 \% ; n=75)$ knew about HIV, only $89.3 \%(n=67)$ gave correct answers about AIDS (indicating that AIDS is an infectious disease caused by HIV which destroys the immune system, making one susceptible to infections). Learners from the private school $(85 \% ; n=17)$, high density school $(86 \% ; n=13)$ and low density school $(90 \% ; n=18)$ trailed behind the rural school $(95 \% ; n=19)$ concerning their levels of AIDS knowledge, as determined by the percentage of correct answers supplied in response to specific questions during the structured interviews.

More female learners $(97.4 \% ; n=38)$ knew about HIV than their male counterparts $(94.4 \% ; n=34)$. However, fewer female learners could define AIDS $(82 \% ; n=32)$, compared to the male learners $(97.2 \% ; n=35)$.

\section{Learners' knowledge about the transmission of HIV}

When learners were asked in an open- ended question how HIV is transmitted, $96 \%(n=72)$ mentioned unprotected sex; $82.7 \%(n=62)$ sharp objects; $25.3 \%(n=19)$ parent to child transmission (PTCT), 13.3\% $(n=10)$ body fluids whilst $9.3 \%$ $(n=7)$ mentioned other ways, including accidents, being scratched by an infected person's nails, and looking after someone who is HIV positive. Unprotected sex, as the most common method of HIV transmission (WHO 2004:5), was mentioned by almost all $(96 \% ; n=72)$ learners. 
As indicated in Table 1, all learners $(100 \% ; n=75)$ knew that having sex with an infected partner could cause HIV infection, that a person could not become infected through mosquito bites $(94.7 \% ; n=71)$, nor from eating from the same plates as infected persons $(98.7 \% ; n=74)$, nor from using the same toilets as infected persons $(97.3 . \% ; n=73)$, nor through coughing $(97.3 \% ; n=73)$. Knowledge about infection through parent to child transmission was high $(94.7 \% ; n=71)$ and infection through needle prick injuries $(96 \% ; n=72)$. Fewer learners knew that HIV infections could occur through blood transfusions $(74.7 \% ; n=56)$ and tattooing $(48.2 \% ; n=36)$.

Of the learners, $96 \%(n=72)$ knew that an HIV positive person could appear healthy. All learners $(100 \% ; n=75)$ mentioned that boys who used the services of prostitutes could acquire HIV and AIDS and other sexually transmitted infections. Learners indicated that the risks of having sex with older men included acquiring HIV and AIDS (89.3\%; $n=67)$, being infected with Sexually Transmitted Infections (STIs) (5.3\%; $n=4)$ and becoming pregnant $(18.7 \% ; n=14)$. The girls' loss of virginity $(1.3 \% ; n=1)$ and the possibility of being murdered $(2.7 \% ; n=2)$ were also mentioned as risks.

\section{Knowledge about cures for AIDS}

Of the learners, $86.7 \%(n=65)$ knew there was no cure for AIDS whilst only $2.7 \%(n=2)$ reported that there was a cure. Most learners $(97.3 \% ; n=73)$ believed that sleeping with a virgin could not cure AIDS whilst 2.7\% $(n=2)$ reported that this behaviour could cure AIDS.

\section{Knowledge about HIV prevention}

Learners were requested to mention three preventive actions that would ensure that they could remain HIV negative. These responses included abstinence $(66.7 \% ; n=50)$, being faithful $(21.3 \% ; n=16)$, using condoms $(66.7 \% ; n=50)$ and 'other' $(85.3 \% ; n=64)$. 'Other methods', mentioned by the learners, included avoiding sharing sharp objects, being tested for HIV before marriage and avoiding peer pressure for risky behaviour as ways of ensuring that they remain HIV negative.

Of the learners, $28 \%(n=21)$ spontaneously mentioned three different ways of avoiding HIV infection, 56\%. $(n=42)$ mentioned two ways and $14.7 \%(n=11)$ only mentioned one way, and one learner failed to mention any method of preventing HIV infection.

Of the learners, 93.3\% $(n=70)$ reported that they had never been tested for HIV whilst $6.7 \%(n=5)$ had been tested. However, $70.7 \%(n=53)$ reported that they wanted to be tested for HIV but $29.3 \%(n=22)$ did not want to do so. Out of the 70 learners who had not been tested, 31.4\% $(n=22)$ reported that they did not want to be tested for HIV and $68.6 \%(n=48)$ were willing to be tested. All the learners who had been tested previously $(6.7 \% ; n=5)$ wanted to be tested again for HIV.

Although 62.7\% $(n=47)$ of the learners did not know of anyone who had tested HIV negative, 54.7\% $(n=41)$ also did not know anyone who had tested HIV positive, but 16 $(n=12)$ knew one person, $10.7 \%(n=8)$ knew two people, $6.7 \%$ $(n=5)$ knew three people, $2.7 \%(n=2)$ knew four people, $4 \%$ $(n=3)$ knew five people and 1.3\% $(n=1)$ knew seven or more people who had tested HIV positive.

\section{Learners' reported sexual behaviours}

Of the learners $94.7 \%(n=71)$ reported that they had never been involved in kissing whilst 5.3\% $(n=4)$ reported having done so. All the learners $(100 \% ; n=75)$ reported that they had never been involved in fondling nor in sexual activity.

Most learners $(80 \% ; n=60)$ did not consider themselves to be at risk of HIV infection, whilst only $18.7 \%(n=14)$ considered that they were at risk. Of the learners $54.7 \%(n=41)$ reported that they were not at risk because they had never had sex before, $8 \%(n=6)$ reported that they did not share needles or razor blades with anyone, $2.7 \%(n=2)$ believed that they were at no risk because there was no one in their family who was HIV positive, whilst $1.3 \%(n=1)$ considered that they were not at risk because their parents were HIV negative, and 1.3\% $(n=1)$ reportedly thought himself or herself not at risk because he or she knew how to prevent HIV infection. However, 2.7\% $(n=2)$ reported that they could be at risk if they dated someone who was infected with HIV, whilst $1.3 \%(n=1)$, felt at risk because he or she could become infected through injuries in an accident or during sexual abuse $(1.3 \% ; n=1)$.

\section{Ethical considerations}

The ethical principles of beneficence, respect for human dignity and justice were considered. The principle of

TABLE 1: HIV transmission responses to yes or no questions $(n=75)$.

\begin{tabular}{|c|c|c|c|c|c|c|c|}
\hline \multirow[t]{2}{*}{ Questions } & \multirow{2}{*}{$\begin{array}{c}\text { Responses } \\
\text { Yes or no }\end{array}$} & \multicolumn{2}{|c|}{ Correct response } & \multicolumn{2}{|c|}{ Incorrect response } & \multicolumn{2}{|c|}{ Total } \\
\hline & & $n$ & $\%$ & $n$ & $\%$ & $N$ & $\%$ \\
\hline Sex with an infected partner & yes & 75 & 100.0 & 0 & 0.0 & 75 & 100 \\
\hline Using same plates as infected persons & no & 74 & 98.7 & 1 & 1.3 & 75 & 100 \\
\hline Cough & no & 73 & 97.3 & 2 & 2.7 & 75 & 100 \\
\hline Using same toilets as infected persons & no & 73 & 97.3 & 2 & 2.7 & 75 & 100 \\
\hline Needle prick injuries & yes & 72 & 96.0 & 3 & 4.0 & 75 & 100 \\
\hline Parent to child transmission & yes & 71 & 94.7 & 4 & 5.3 & 75 & 100 \\
\hline Blood transfusion & yes & 56 & 74.7 & 19 & 25.3 & 75 & 100 \\
\hline Tattooing & yes & 36 & 48.0 & 39 & 52.0 & 75 & 100 \\
\hline
\end{tabular}

$n$, number of participants; $N$, Total number of participants. 
beneficence requires that the researchers should commit no harm (Polit \& Hungler 2008:31), including freedom from exploitation, benefits of research and the risk to benefit ratio. The respondents were informed about the study, and its benefits and risks. Written permission from each learner's parent or legal guardian was obtained before the interview was conducted, provided that the individual learner was willing to be interviewed.

Ethical clearance to conduct the study was granted by the Research and Ethics Committee of the Department of Health Studies, University of South Africa, Zimbabwe's Ministry of Education, Sports and Culture (MOESC) and the management of each participating school.

The principle of respect for human dignity requires that the right to self determination and full disclosure were respected (Polit \& Hungler 2008:33). This was achieved by providing information about the study to enable each learner to decide whether or not to participate, without incurring any penalties. No learner was forced to participate.

The principle of justice demands fair treatment and the right to privacy (Polit \& Hungler, 2008:35). No identifying information was collected from any learner and confidentiality was ensured throughout the research process. No signed consent was requested from individual learners, but the researcher asked every interviewee the following questions:

- 'Your parent or guardian signed consent for you to participate in the study. Are you willing to be interviewed by me?

- Do you understand that you may refuse to answer specific questions and you may stop being interviewed at any stage?'

Only learners, who answered positively to both questions, were interviewed. No identification details were entered onto any interview schedule, thus safeguarding the learners' anonymity. No names of the participating schools would be disclosed. Information shared with the interviewer was not divulged to any other person. The completed interview schedules were kept under lock and key and would be destroyed after the acceptance of the research report. Only the researchers and the statistician had access to the raw data.

\section{Validity and reliability of the instrument}

The reliability of an instrument can be measured by means of stability, internal consistency and equivalence. Stability of an instrument is the extent to which the same results are obtained on repeated administrations of the same instrument (Polit \& Hungler 2008:368). Stability of the instrument was checked by pre-testing the interview schedule in two schools (that were excluded from the actual study) and the results of the pre-tests were compared with those from the actual data collection phase. No major discrepancies were identified. Internal consistency implies that all subparts of an instrument measure the same characteristics (Polit \& Hungler 2008:371), judged to be the case by two researchers and a statistician. Equivalence was not applied to this instrument.

To enhance validity, the instrument was developed using questions similar to those from research reports assessing HIV knowledge and sexual behaviours. The instrument was reviewed by two experienced researchers and a statistician. These persons accepted that the items on the structured interview schedule reflected the real meaning of the concept under consideration, namely the HIV and AIDS knowledge and sexual behaviour of the learners (Babbie \& Mouton 2001:142).

\section{Discussion}

\section{Sources of HIV and AIDS information}

All 75 learners (100\%) had heard about HIV and AIDS. These results are higher than those of an earlier Zimbabwe survey (MOHCW 2001-2002:100) in which 38\% of females and 58\% of males reported the school as a source of HIV and AIDS information before they reached the age of 15 . This might indicate that Zimbabwe's HIV and AIDS school programme has reached the Form 1 learners. However, the school was not the only place where learners obtained HIV and AIDS information. Zimbabwe broadcasts a variety of HIV and AIDS television programmes, which explains why $60 \%(n=45)$ of learners reported television as their source of information. HIV and AIDS information was also provided by other sources including parents $(13.3 \% ; n=10)$, newspapers $(9.3 \%$; $n=7)$ and community activities $(4 \% ; n=3)$. Parents ranked low as sources of information for the learners $(13.3 \% ; n=10)$, and this probably indicates that sexual behaviour and related issues were not discussed openly in these learners' homes. According to another survey the two most common sources of HIV and AIDS information (MOHCW 2005:105) were pamphlets, posters and the radio for more than $60 \%$ of those respondents. As this study's data were collected during 2008, Zimbabwe's school HIV and AIDS programme might have had some impact, on its learners' knowledge about HIV and AIDS, from 2005 till 2008.

\section{Learners' HIV and AIDS knowledge}

Although $100 \%(n=75)$ of the learners had heard about HIV, 94.7\% $(n=71)$ could describe what HIV implied and 89.3\% ( $n=67$ ) could describe what they understood AIDS to be. Learners from the rural school were more knowledgeable about HIV and AIDS than those from other schools. No reasons could be offered for the apparent better HIV and worse AIDS knowledge of female learners compared to their male counterparts.

This matches the Zimbabwe Demographic and Health Survey (ZDHS 2005-6:184) report stating that in the population aged 15-49, the knowledge levels of HIV and AIDS were 98\% amongst women and 99\% amongst men. According to the ZDHS (2005-6:184) report, young people aged 15-24 generally had lower levels of HIV and AIDS knowledge than those in older age groups. 
Unprotected sex, as the most common method of HIV transmission (WHO 2004:5), was mentioned by almost all (96\%; $n=72$ ) the learners. However, if the school HIV and AIDS programme had been effective, every learner should have known this. The statistics in Table 1 indicate that more than $90 \%$ of the learners were knowledgeable about most transmission methods of HIV. However, learners seemed to lack knowledge about HIV transmission through blood transfusions and tattooing. This might be attributable to the extremely rare circumstances under which blood transfusions could be administered in Zimbabwe and to the learners' potential unfamiliarity with 'tattooing'. However, no learner requested more information about these terms.

Of the learners, $96 \%(n=72)$ knew that a person who is HIV positive could appear healthy. The results are higher than the findings of the Zimbabwe's Young Adult Survey (MOHCW 2001-2:71) in which $73 \%$ of young women and $77 \%$ of young men knew that a person infected with HIV could look healthy. If the school HIV and AIDS programme had been successful, $100 \%$ of the learners should have had this knowledge.

All learners knew that boys who used the services of prostitutes could become infected with HIV, and almost all of them $(89.3 \% ; n=67)$ knew that girls who have sex with older men risked becoming HIV positive. It could not be ascertained why $100 \%$ of the learners were not knowledgeable about this possibility which should be stressed in the HIV and AIDS school programme.

Although $86.7 \%(n=65)$ of the learners knew that there was no cure for AIDS and 97.3\% $(n=73)$ believed that having sex with a virgin could not cure AIDS, all learners did not know these basic facts. These aspects could indicate shortcomings in the HIV and AIDS school programme.

\section{Knowledge about the prevention of HIV}

Only $28 \%(n=21)$ of the learners spontaneously mentioned three methods of ensuring that one could remain HIV negative (abstinence, being faithful, using condoms). Only $66.7 \%(n=50)$ of the learners mentioned condoms, implying that $32.3 \%(n=25)$ of the learners had not been convinced that condoms would prevent HIV infections. If the school HIV and AIDS programme had been successful, 100\% of the learners should have spontaneously mentioned the ABC of HIV prevention, and $100 \%$ should have mentioned the use of condoms.

Although $93.3 \%(n=70)$ of the respondents had never been tested for HIV, $70.7 \%(n=53)$ wanted to be tested. All the learners who had been tested previously $(6.7 \% ; n=5)$ wanted to be tested again for HIV. This finding indicates that many learners who were willing to access VCT services, had not yet done so, and should be assisted to access VCT services. School HIV and AIDS programmes should address ways to access VCT services. The fact that all previously tested learners were willing to be re-tested could indicate that they did not experience VCT negatively.

\section{Learners' reported sexual behaviours}

Reportedly all 75 (100\%) respondents had never been involved in sex nor in fondling. This finding seems to correspond with data obtained in Zimbabwe showing that the 6-15 year age group is least affected by HIV and AIDS (MOHCW 2004:4). However, these findings do not compare with the results of a study indicating that almost one third of the 12-14 year old girls and boys in Uganda and Malawi (Bankole, Biddlecom, Guiella, Singh \& Zulu 2007:1) had experienced some form of intimate sexual activity. In Burkina Faso and Ghana one out of ten adolescents had been involved in some form of sexual activity (Bankole et al. 2007:1). If this study's reported abstinence amongst Form 1 learners could be substantiated by future surveys, then Zimbabwe's HIV and AIDS school programme might have achieved some impact on learners to delay their sexual debuts.

\section{Limitations of the study}

The research results are limited to Form 1 learners from the four participating schools. However, the sample comprised learners from the rural, high density, low density and private schools, representing the four types of schools in Zimbabwe. The demographic characteristics of the learners were comparable across the four schools, as well as to those reported by the Zimbabwe Demographic and Health Survey (ZHDS 2005-6:158).

Only 75 learners were interviewed because the interviews were conducted at a time when there were few teachers and learners at schools, resulting from teachers striking for better salaries. Only learners who were willing to be interviewed could participate in this study. There can be no guarantee that learners unwilling to be interviewed had similar levels of HIV and AIDS knowledge. The relatively small sample size of 75 learners was a limitation in itself. As a convenience sample was used, only descriptive statistical analyses could be applied to the results.

Reportedly none of the interviewed learners had been sexually active, which made questions about sexual practices irrelevant, and the study was, thus, incapable of reporting on these issues. The responses of the learners might have been influenced by the presence of the interviewer. The researchers were advised by teachers and healthcare professionals, to select structured interviews, and not selfcompletion questionnaires, to obtain information about the knowledge of HIV and AIDS of secondary school learners. Form 1 learners in Harare, might have been unable to complete questionnaires on their own, resulting in vast numbers of unanswered questions, rendering the raw data relatively useless.

\section{Recommendations}

As most, learners acquired their HIV and AIDS information from schools, and these school-based programmes should be sustained, improved and expanded. Based on the fact that the minority of learners acquired their HIV and AIDS information 
from their parents, school-based parent-empowering HIV and AIDS and sex-related education programmes should be provided to parents, in addition to those existing for learners.

The school curriculum needs to be revised to emphasise improving the learners' knowledge about HIV and AIDS and to address misconceptions (even if only held by a minority of learners). These misconceptions include HIV and AIDS transmission through being scratched by the nails of a person who is HIV positive, the fact that there is no cure for HIV and AIDS and the fact that HIV and AIDS cannot be cured by having sex with a virgin. The school-based HIV and AIDS programme should also stress that, provided that one takes precautionary measures to protect oneself against contamination with the HIV positive person's body fluids, one is unlikely to become HIV infected whilst caring for such a person. The school curriculum should also emphasise the difference between HIV and AIDS and should ensure that every learner knows the ABC of HIV and AIDS prevention.

The finding, that $80 \%(n=60)$ of the learners did not consider themselves to be at risk of contracting HIV and AIDS, should be addressed by HIV and AIDS programmes, which should emphasise that every person can be at risk. Radio and television programmes, targeting young people with HIV and AIDS information, should be sustained, monitored and expanded.

Future studies should involve learners from Forms 1 to 5 (Grades 8-12), to identify the average ages at which secondary school learners commence sexual activities. Ideally a randomly selected sample of all secondary school learners throughout Zimbabwe should participate in a study to evaluate the HIV and AIDS knowledge level of all Zimbabwe's learners, and to redesign the HIV and AIDS school curriculum accordingly.

As most learners were willing to undergo VCT, these services should be made accessible to secondary school learners in Zimbabwe.

\section{Conclusion}

All the learners reported that they were not sexually active and were aware of the dangers of being involved in high risk behaviours like having sex with prostitutes or older men. Although knowledge about HIV transmission was high, fewer than one third of the learners $(28 \% ; n=21)$ could mention three ways of preventing HIV infection.

All learners had heard about HIV and AIDS and the school was the most frequently mentioned source of information, followed by television, radio, parents, newspapers and community activities. Although the school HIV and AIDS programme had achieved some successes, its impact could be enhanced, as well as HIV and AIDS messages, through television, radio and parents and, furthermore, community activities should be encouraged. Every learner should be able to define HIV, AIDS and the ABC of preventing HIV infections.
More than half of the learners were reportedly willing to undergo VCT, but most had not done so. Making VCT services available to secondary school learners should be prioritised to enable this age group to make informed decisions, that affect themselves and their future children. School HIV and AIDS programmes should enable learners to access VCT services.

The HIV and AIDS school programme in Zimbabwe should be assessed regularly, to measure its impact on the knowledge levels of secondary school learners about HIV and AIDS. Based on the research findings, the HIV and AIDS curriculum should be adapted at regular intervals to address identified shortcomings.

\section{Acknowledgement}

The authors wish to thank all persons who granted them permission to conduct the study, all parents who permitted their children to participate in the study and all learners who shared their experiences with the interviewer.

\section{Competing interest}

The authors declare that they have no financial or personal relationship(s) which may have inappropriately influenced them in writing this article.

\section{Authors' contributions}

M.M. MPH student (University of South Africa), project leader and interviewer, V.J.E. (University of South Africa) joint supervisor who wrote the manuscript, J.H. R. (University of South Africa) supervisor and co-author of the manuscript.

\section{References}

Babbie, E.R. \& Mouton, J., 2001, The practice of social research, Oxford University Press, Cape Town.

Bankole, A., Biddlecom, A., Guiella, G., Singh, S. \& Zulu, E., 2007, 'Sexual behaviour, knowledge and information sources of very young adolescents in four Sub-Saharan African countries', African Journal of Reproductive Health 11(3): 28-43. http://dx.doi.org/10.2307/25549730, PMid:18458739

Boohene, E., Tsodzai, J., Hardee-Cleveland, K., Weir, S. \& Janowitz, B. 1999, 'Fertility and contraceptive use among adults in Harare, Zimbabwe', Studies in Family and contraceptive use among adults in Harare, Zimbabwe', Studies in Fam
Planning 22(4): 264-271. http://dx.doi.org/10.2307/1966482, PMid:1949108

Brink, H.I.L., 2006, Research methodology for health care professionals, Juta, Cape Town.

Burns, N. \& Grove, N.K. 2001, The practice of nursing research: conduct, critique and utilization, 4th edn., W.B. Saunders, Philadelphia.

Buseh, A.G., Glass, L.K., McElmurry, B.J., Mkhabela, M. \& Sukati, N.A., 2001, 'Primary and preferred sources for HIV/AIDS and sexual risk behaviour information among adolescents in Swaziland, Southern Africa', International Journal of Nursing Studies 39(2002): 525-538. http://dx.doi.org/10.1016/S0020-7489(01)00058-X

Freudenthal, S, 2001, A review of social science research on HIV/AIDS, Department for Research Cooperation, Sida.

Fritz, K.E., Woelk, G.B., Bassett, M.T., McFarland, W.C., Routh, J.A., Tobaiwa, O. \& Stall, R.D., 2002, 'The association between alcohol use, sexual risk behaviour and HIV infection among men attending beer halls in Harare, Zimbabwe', AIDS and Behaviour 6(3): 221-228. http://dx.doi.org/10.1023/A:1019887707474

Joint United Nations Programme on HIV/AIDS, 2004, Report on global Aids epidemic, 4th Global Report, Geneva.

Joint United Nations Programme on HIV/AIDS, 2006, $6^{\text {th }}$ Report on the global Aids epidemic, Geneva.

Lindsay, E., 2001, 'Fact sheets of HIV/AIDS for nurses and midwives', Supplement to Africa Journal of Nursing and Midwifery 3(1): S1-S10.

Mataure, P.M.T., McFarland, W.C., Fritz, K.E., Kim, A., Woelk, G., Ray, S. \& Rutherford, G., 2002, 'Alcohol use and high-risk behaviour among adolescents and young adults in Harare, Zimbabwe', Zimbabwe AIDS and Behaviour 6(3): 211-219. http://dx.doi.org/10.1023/A:1019835723404 
Ministry of Education, Sports and Culture, Zimbabwe, 2003, Zimbabwe HIV/AIDS and life skills education, Government Printer, Harare.

Ministry of Education, Sports and Culture, Zimbabwe, 2005, Zimbabwe Ministry of Education annual report, Government Printer, Harare.

Ministry of Health and Child Welfare, Zimbabwe, 1999, National Aids Policy, Government Printer, Harare.

Ministry of Health and Child Welfare, Zimbabwe, 2000, National AIDS Control Programme, Government Printer, Harare.

Ministry of Health and Child Welfare, Zimbabwe, 2001-2002, The Zimbabwe young adult survey (ZYAS), Government Printer, Harare

Ministry of Health and Child Welfare, Zimbabwe, 2003. The HIV/AIDS epidemic in Zimbabwe, Government Printer, Harare.

Ministry of Health and Child Welfare, Zimbabwe, 2004, The HIV/AIDS epidemic in Zimbabwe, Government Printer, Harare.
Ministry of Health and Child Welfare, Zimbabwe, 2005, Zimbabwe Ministry of Health Annual report, Government Printer, Harare.

Ministry of Youth Development, Gender and Employment Creation, Zimbabwe, 2000 National Youth Policy of Zimbabwe, Government Printer, Harare.

Phiri, A., 2000, Experiences of youth in urban Zimbabwe, Population Council, Nairobi. Polit, D.F. \& Hungler, B.P., 2008, Nursing research: generating and assessing evidence for nursing practice, Lippincott, Williams \& Wilkins, Philadelphia.

United Nations International Children's Emergency Fund, 2002, Young people and HIV/AIDS: opportunity in crisis, Geneva.

World Health Organization, 2004, HIV /AIDS in Adolescence. Geneva.

World Health Organization, 2006, Approach to adolescents. Geneva.

Zimbabwe Demographic and Health Survey, 2005-2006, HIV/AIDS. Government Printer, Harare. 